Article

\title{
Bovine Lactoferrin Inhibits Toscana Virus Infection by Binding to Heparan Sulphate
}

\author{
Agostina Pietrantoni ${ }^{1}$, Claudia Fortuna ${ }^{2}$, Maria Elena Remoli ${ }^{2}$, Maria Grazia Ciufolini ${ }^{2}$ \\ and Fabiana Superti ${ }^{1, *}$
}

1 Department of Technology and Health, Istituto Superiore di Sanità, Viale Regina Elena, 299, Rome 00161, Italy; E-Mail: agostina.pietrantoni@iss.it

2 Department of Infectious, Parasitic and Immune-mediated Diseases, Istituto Superiore di Sanità, Viale Regina Elena, 299, Rome 00161, Italy; E-Mails: claudia.fortuna@iss.it (C.F.); mariaelena.remoli@iss.it (M.E.R.); mariagrazia.ciufolini@iss.it (M.G.C.)

* Author to whom correspondence should be addressed; E-Mail: fabiana.superti@iss.it; Tel.: +39-064-990-3149; Fax: +39-064-990-3563.

Academic Editor: Curt Hagedorn

Received: 1 December 2014 / Accepted: 23 January 2015 / Published: 29 January 2015

\begin{abstract}
Toscana virus is an emerging sandfly-borne bunyavirus in Mediterranean Europe responsible for neurological diseases in humans. It accounts for about $80 \%$ of paediatric meningitis cases during the summer. Despite the important impact of Toscana virus infection-associated disease on human health, currently approved vaccines or effective antiviral treatments are not available. In this research, we have analyzed the effect of bovine lactoferrin, a bi-globular iron-binding glycoprotein with potent antimicrobial and immunomodulatory activities, on Toscana virus infection in vitro. Our results showed that lactoferrin was capable of inhibiting Toscana virus replication in a dose-dependent manner. Results obtained when lactoferrin was added to the cells during different phases of viral infection showed that lactoferrin was able to prevent viral replication when added during the viral adsorption step or during the entire cycle of virus infection, demonstrating that its action takes place in an early phase of viral infection. In particular, our results demonstrated that the anti-Toscana virus action of lactoferrin took place on virus attachment to the cell membrane, mainly through a competition for common glycosaminoglycan receptors. These findings provide further insights on the antiviral activity of bovine lactoferrin.
\end{abstract}


Keywords: Toscana virus; lactoferrin; antiviral agents; Phlebovirus

\section{Introduction}

Toscana virus (TosV) (family Bunyaviridae, genus Phlebovirus) is an enveloped, negative-stranded RNA virus, with a genome consisting of three segments: small (S), medium (M), and large (L), encoding the nucleoprotein (N) and a non-structural protein (NSs), the envelope glycoproteins (GN and GC), and a non-structural protein (NSm), and the large protein (L, the viral RNA-dependent RNA polymerase), respectively [1,2]. It was first isolated in 1971 from sandfly, Phlebotomus perniciosus, collected in the Toscana region of Central Italy [3,4]. Following its discovery, several other regions of Italy, where the insect vectors (Phlebotomus perniciosus and Phlebotomus perfiliewi) are present [5], showed to be endemic. Although Tos $\mathrm{V}$ rarely gives rise to clinical infection, in these regions it was responsible for neuroinvasive infections during the summertime [6-10]. Moreover, other Mediterranean Countries, including Spain, France, Portugal, Cyprus, Greece, and Turkey, have been included in the endemic regions of Tos $\mathrm{V}$ [11]. Tos $\mathrm{V}$ represents the only sandfly-transmitted virus that demonstrates neurotropic activity to date [12,13], particularly during the summer, with a peak in August, correlating with the activity of phlebotomus vectors [14-20]. Infections without central nervous system involvement have also been described [15].

Tos V clinical infection starts as a mild febrile illness, following an incubation period of three to seven days, without involvement of the central nervous system (CNS) [5]. Neuroinvasive infections usually begin with headache, fever, nausea, vomiting, and myalgia. Physical examination may show neck rigidity, Kernig sign, and, in some cases, unconsciousness, tremors, paresis, and nystagmus. The outcome is usually favorable without significant sequelae. Other clinical manifestations have been reported, such as encephalitis [21], severe meningo-encephalitis [22], testicular involvement [23], deafness [24,25], persistent personality alterations [26], long-lasting unconsciousness with seizures, prolonged convalescence [27], and even fatal encephalitis [28].

Despite the important impact of TosV infection-associated disease on human health, there are currently no available approved vaccines or specific antiviral therapies for this disease.

Bovine lactoferrin (bLf) is a glycoprotein, consisting of a single polypeptide chain of 689 amino acidic residues, with a molecular mass of about $80 \mathrm{kDa}$, which binds two iron atoms with very high affinity [29]. Such a protein has an alkaline isoelectric point (about pI 9) and its cationic nature could have a major role in the ability to bind cells and many anionic molecules, such as glycosaminoglycans (GAGs) and lipopolysaccharide. BLf is present in various biological fluids and in specific granules of polymorphonuclear leukocytes [30], and possesses a variety of biological functions, such as promotion of iron absorption, immunomodulation, and inhibiting activity towards different pathogens [31-34]. In particular, bLf has been recognized as potent inhibitor of different enveloped viruses, such as human cytomegalovirus [35,36], Herpes Simplex Viruses types 1 and 2 [37-40], Human immunodeficiency virus [35], Human hepatitis C virus [41], Hantavirus [42], Hepatitis B virus [43], Respiratory syncytial virus [44], Influenza virus [45,46], Flavivirus [47], and Alphavirus [48]. 
In an effort to identify antiviral therapies effective against $\operatorname{Tos} \mathrm{V}$, in this research we have analyzed the effect of bLf on virus infection in vitro. Our results indicate that bLf treatment specifically inhibits viral cytopathic effect and that its action takes place in an early phase of infection. In particular, bLf has been found to prevent viral infection by binding to GAGs, which, in turn, can act as cell receptors for TosV.

\section{Results}

\subsection{Activity of bLf on TosV Cytopathic Effect}

A preliminary set of experiments was carried out to determine the maximal non-cytotoxic concentration of bLf. For this purpose, twofold serial dilutions of protein from $2 \mathrm{mg} / \mathrm{mL}$ in DMEM were incubated with Vero cells for 48 and $72 \mathrm{~h}$ at $37^{\circ} \mathrm{C}$. Under these conditions, bLf did not affect any of the cytotoxicity parameters up to the highest dose. To establish whether bLf could inhibit TosV cytopathic effect (c.p.e.) in Vero cells, two-fold serial dilutions of lactoferrin, starting from the highest non-cytotoxic concentration, were incubated with the cells through the infection (before, during, and after virus adsorption). In our experimental conditions, bLf showed dose-dependent inhibitory activity (Figure 1).

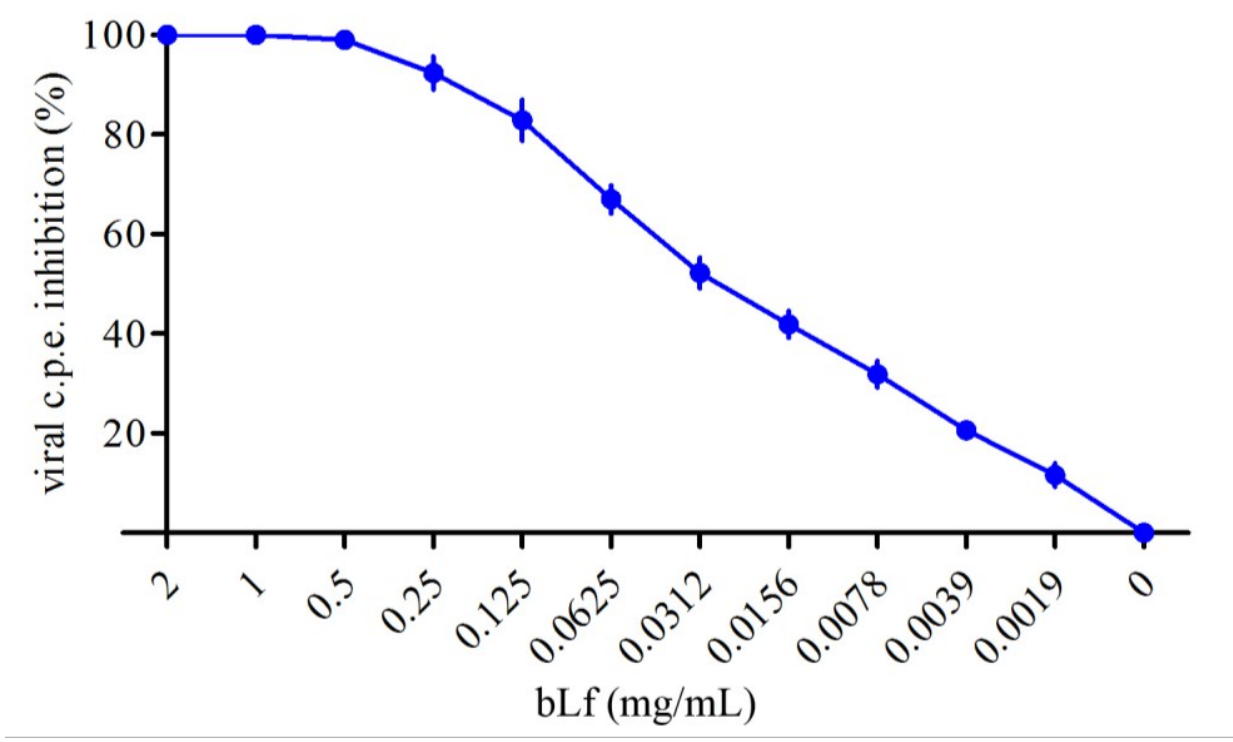

Figure 1. Dose-response curve of bLf toward TosV cytopathic effect in Vero cells. Vero cells were infected with virus (m.o.i. 1). BLf was incubated at different concentrations with the cells before $\left(1 \mathrm{~h}\right.$ at $\left.37^{\circ} \mathrm{C}\right)$ and during $\left(1 \mathrm{~h}\right.$ at $\left.37^{\circ} \mathrm{C}\right)$ the viral absorption step and newly added after the removal of virus inoculum. At $48 \mathrm{~h}$ post-infection, the percentage of c.p.e. was evaluated. Data showed represent the mean of at least quadruplicate samples.

\subsection{Effect of bLf on Different Steps of Viral Infection}

To ascertain whether the antiviral effect of bLf took place on viral adsorption or at a different step of viral replication, the inhibiting activity of protein $(1 \mathrm{mg} / \mathrm{mL})$ was assessed by following different experimental procedures: (i) the cells were incubated with bLf $\left(1 \mathrm{~h}\right.$ at $\left.37^{\circ} \mathrm{C}\right)$, washed three times with medium and then infected $\left(1 \mathrm{~h}\right.$ at $\left.37^{\circ} \mathrm{C}\right)$; (ii) bLf was added, together with the virus inoculum, during the adsorption step $\left(1 \mathrm{~h}\right.$ at $\left.37^{\circ} \mathrm{C}\right)$; (iii) bLf was incubated with the cells after the viral adsorption step 
(48 $\mathrm{h}$ at $37^{\circ} \mathrm{C}$ ); (iv) bLf was present during the whole experiment. TosV c.p.e. was measured by neutral red uptake assay. Results reported in Figure 2 show that a high inhibition was obtained under the conditions used in procedures (ii) and (iv).

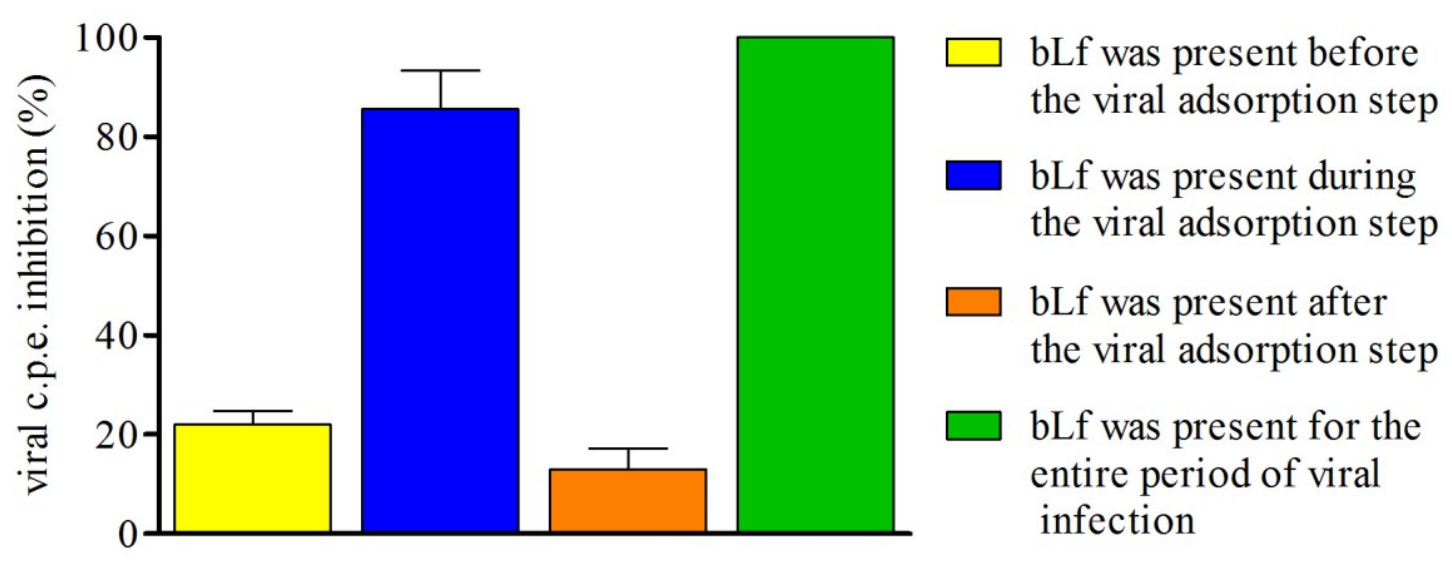

Figure 2. Effect of bLf on different steps of TosV infectious cycle. Monolayers of Vero cells were infected with TosV (m.o.i. 1) and treated with bLf $(1 \mathrm{mg} / \mathrm{mL})$ during different phases of infection: (A) before virus inoculation; (B) during virus inoculation; (C) after virus inoculation; and (D) throughout infection. After $48 \mathrm{~h}$ of infection the viral c.p.e. was measured by neutral red uptake assay. Data showed represent the mean of at least quadruplicate samples.

\subsection{Neutralization of TosV Infection by Heparin}

Our results indicated that the anti-Tos V activity of bLf is mainly directed on viral attachment to target cells. It has been reported that GAGs, like heparin and heparan sulphate (HS), participate to the attachment of bLf to target cells [49]. Moreover, Rift Valley fever virus (RVFV), an emerging arthropod-borne pathogen belonging to the Phlebovirus genus of the Bunyaviridae family, has been demonstrated to bind to GAGs for entry susceptible cells [50]. Our hypothesis was that, if TosV also requires GAGs for the attachment to and entry into the target cells, bLf inhibitory activity might be due to a competition with the virus for a common receptor.

To explore whether GAGs are used for viral attachment, we examined whether, and to what extent, heparin, often used experimentally as an HS analog, could affect virus replication. This was tested by neutral red staining measuring of virus-infected Vero cells as a measure of cell viability. Results obtained showed that viral cytopathic effect was markedly inhibited by pre-incubation with heparin with a dose-dependent relationship (Figure 3). 


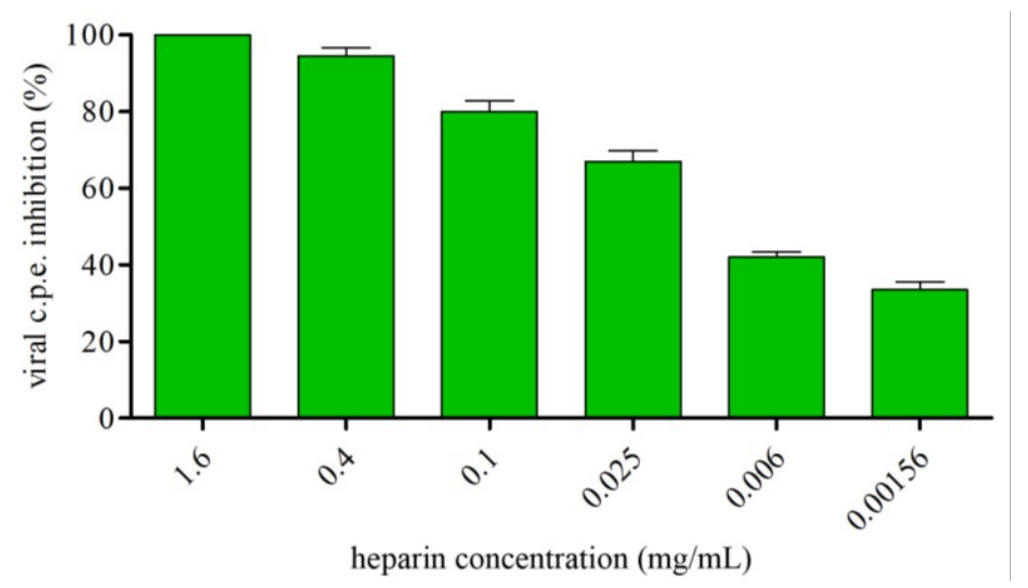

Figure 3. Tos V infection is decreased in the presence of heparin. Tos V was incubated with different concentrations of heparin for $1 \mathrm{~h}$ at $37^{\circ} \mathrm{C}$ in culture medium prior to infection of Vero cells. At $48 \mathrm{~h}$ post infection c.p.e. was measured by neutral red uptake assay. The data shown correspond to the results of a representative set of two independent experiments performed in quadruplicate.

\subsection{Modulation of Infectivity by Enzyme Treatment of Cell Surface GAGS}

To confirm the role of GAGs on TosV-cell interactions, further experiments were carried out based on the hypothesis that if cell-surface GAGs modulate infection, their enzymatic digestion should decrease the viral infectivity. Cells were incubated with heparinase I, specific for heparin and highly sulfated domains, heparinase II, specific for heparin and heparan sulfate, and heparinase III, specific for heparan sulfate [51].

Treatment of Vero cells with each of the heparinases for $1 \mathrm{~h}$ at $37{ }^{\circ} \mathrm{C}$ was found to reduce viral infection, significantly, in a dose-dependent manner. In particular, treatment of cells with heparinases I, II, and III at $2.5 \mathrm{U} / \mathrm{mL}$ significantly inhibited TosV infection by $65.2 \% \pm 6.6 \%, 50.1 \% \pm 4.8 \%$, and $97.6 \% \pm 2.0 \%$, respectively (Figure 4 ).

These results confirm that HS moiety of GAGs expressed on the cell surface intervenes in TosV-mediated infection.

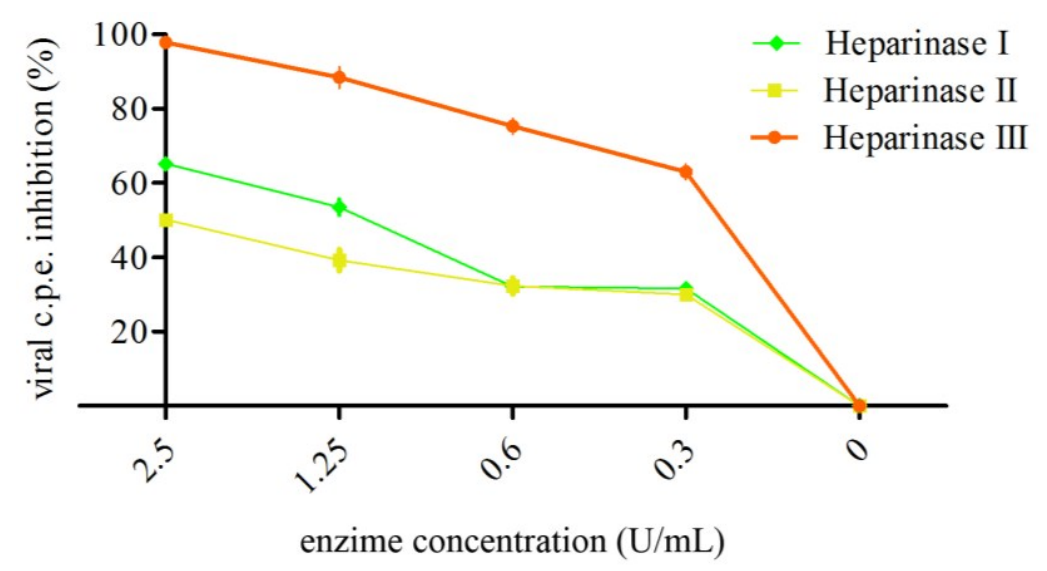

Figure 4. Modulation of infectivity by enzyme treatment of cell surface GAGs. GAGs were enzymatically removed from the cell surface of Vero cells by treating the cells for $1 \mathrm{~h}$ at 
$37{ }^{\circ} \mathrm{C}$ with heparinase I, II, or III at the indicated concentrations. The cells were washed twice with culture medium and then infected with TosV for $1 \mathrm{~h}$ at $37{ }^{\circ} \mathrm{C}$. After $48 \mathrm{~h}$ of infection the viral c.p.e. was measured by neutral red uptake assay. The data shown correspond to the results of a representative set of two independent experiments performed in quadruplicate.

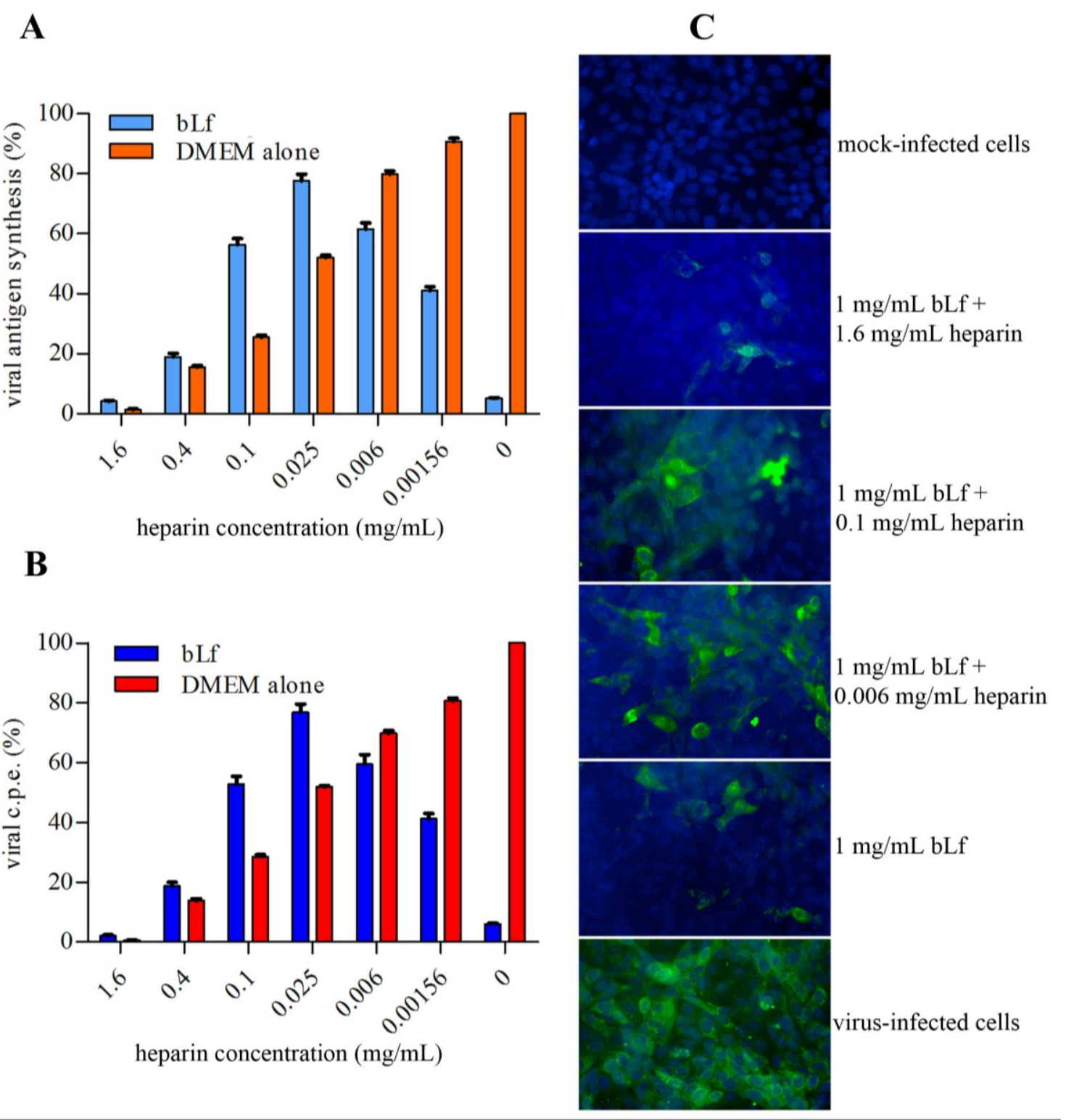

Figure 5. Effect of heparin and bovine lactoferrin (bLf) in combination on TosV infection. $\operatorname{BLf}(1 \mathrm{mg} / \mathrm{mL})$ and heparin, one at a time or mixed together, were incubated with Vero cells during the virus adsorption step $\left(1 \mathrm{~h}\right.$ at $\left.37^{\circ} \mathrm{C}\right)$. (A) After $18 \mathrm{~h}$ incubation at $37^{\circ} \mathrm{C}$, viral replication was monitored by immunofluorescence and expressed as percentage of viral antigen synthesis; (B) After $48 \mathrm{~h}$ incubation at $37{ }^{\circ} \mathrm{C}$, the percentage of viral c.p.e. was measured by neutral red uptake assay. Data showed represent the mean of at least quadruplicate samples. (C) Representative pictures of fluorescence microscopy. Nuclei were counterstained with 4',6'diamidino-2-phenylindole (DAPI) (magnification, $\times 40$ ). 


\subsection{Effect of Lactoferrin and Heparin on TosV Infection}

As bLf binds GAGs directly, we investigated whether heparin could compete with the activity of bLf against TosV infection. To test the anti-TosV effect of both heparin and lactoferrin in our virus-cell system, bLf $(1 \mathrm{mg} / \mathrm{mL})$ and different concentrations of heparin, one at a time or mixed together, were incubated with Vero cells during the TosV adsorption step $\left(1 \mathrm{~h}\right.$ at $\left.37^{\circ} \mathrm{C}\right)$.

After $18 \mathrm{~h}$ incubation at $37^{\circ} \mathrm{C}$, viral antigen synthesis was monitored by immunofluorescence and expressed as percentage of infected cells (Figure 5A). After $48 \mathrm{~h}$ incubation at $37^{\circ} \mathrm{C}$, the c.p.e. was measured by neutral red uptake assay (Figure 5B).

The results obtained showed that, like lactoferrin, heparin reduced both viral antigen synthesis and c.p.e. in a dose-dependent manner and that at the highest heparin concentration the inhibitory activity on TosV infection was due to heparin and was not modified by the presence of lactoferrin. When the heparin concentration was reduced to $25 \mu \mathrm{g} / \mathrm{mL}$, the inhibitory effect of both compounds was partially abolished. When the heparin concentrations became low $(6 \mu \mathrm{g} / \mathrm{mL})$, the inhibitory effect of bLf was increased, again being evident in the presence of $1.56 \mu \mathrm{g} / \mathrm{mL}$ of heparin.

\section{Discussion}

Lactoferrin exhibits inhibitory activities against a wide range of viruses [52] and it has been reported that human and bovine lactoferrins inhibit the infection of mosquito-borne viruses, such as Sindbis virus and Semliki Forest virus [53], Japanese encephalitis virus [47], and Mayaro virus [48].

$\operatorname{Tos} \mathrm{V}$, the sandfly-borne phlebovirus with the greatest known virulence for humans, possesses a marked tropism for central and peripheral neurological systems and is cause of aseptic meningitis, meningoencephalitis, and encephalitis during the warm seasons in countries in which it circulates [20-22]. The probable underestimation of its spread, due to the high percentage of febrile or asymptomatic cases, makes this virus a "neglected human pathogen". It is known today that TosV circulation is larger than initially believed. Despite increasing evidence of the role of TosV in human public health, up to now there are no available, approved vaccines or specific antiviral therapies for this disease. For this reason, the discovery and/or development of new drugs active against this virus may be useful to reduce the effects of the infection in the most severe forms.

In this paper, we analyzed the activity of bLf against TosV infection in Vero cells. Our results showed that bLf strongly inhibited infection of cells by TosV in a dose-dependent manner. As a matter of fact, at a concentration of $31.25 \mu \mathrm{g} / \mathrm{mL}$ bLf caused a $50 \%$ reduction in viral c.p.e. Regarding the bLf effect on the different steps of viral infection, we observed that the protein mainly acts at the level of cell attachment, interfering with virus-cell binding rather than on virus replication after the cells becomes infected. These results are in agreement with the majority of the studies on the antiviral activity of bLf, suggesting that the protein prevents virus entry into cells instead of later phases of viral replication.

BLf can act on virus cell entry by binding to the viral particles or by binding to host cell molecules that viruses use either as receptors or co-receptors [33]. In this context, binding of bLf to cell-surface heparan sulfate glycosaminoglycans (HS-GAGs) represents a key phenomenon [54,55]. On the other hand, virus-susceptible cell interaction often requires several binding events to productive cell entry [56]. Cell surface HS-GAGs are co-receptors for several pathogens such as parasites, bacteria, and viruses [57]. 
For example different viruses, such as Sindbis virus [58], Venezuelan equine encephalitis virus [59], Adeno-associated virus type 2 [60], Foot-and-mouth disease virus [61], Herpesviruses [62-65], Human immunodeficiency virus [66], Echovirus [67], Dengue virus [51,68], Adenovirus types 2 and 5 [69], and Yellow fever virus [68], interact with GAGs. GAGs are linear polysaccharides that can be attached to proteins to form proteoglycans. There are five classes of GAGs: heparan-, chondroitin-, dermatan-, keratan sulfate, and hyaluronic acid. Heparan-sulfate, unlike other GAGs, is expressed in large quantities on most cell types and has been identified as an attachment factor for several viruses [70]. Concerning phlebovirus, it has been recently demonstrated that the first event in RVFV infection is the attachment to extracellular GAGs and that heparin, a GAG analog of HS, is able to inhibit virus-cell interaction [50].

Based on these observations, we have hypothesized that docking of Tos V to cellular HS might be the initial step in the interaction between virus and the cell surface, and that bLf could exert its anti-TosV action by a competition for a common GAG receptor. To verify this hypothesis we first evaluated whether TosV infection could be neutralized either by heparin, a GAG analog heparan sulphate, or by removal of HS from the cell surface with different heparinases prior to infection. Our results demonstrated that HS-GAGs expressed on susceptible cell surface are involved in the binding of TosV, based on the following evidence: (i) binding and infection are competitively inhibited by pre-incubation of virus with heparin, a soluble receptor analog, in a dose-dependent manner, (ii) enzymatic cleavage of cell-surface HS-GAGs prevents infection.

Finally, to verify if bLf exerts its antiviral action by a competition for a common GAG receptor, experiments were carried out in which different concentrations of bLf and heparin, one at a time or mixed together, were incubated with Vero cells during the viral adsorption step. Our results showed that both bLf and heparin are able to prevent virus attachment to target cells when introduced one at a time. However, the antiviral effect of compounds was partially abolished when heparin and bLf were mixed together at specific concentrations, suggesting that they could interact with each other and that the anti-TosV effect of bLf is due to a direct competition for GAG receptors.

In conclusion, the results in this paper strengthen the knowledge that one way by which lactoferrin may inhibit infection of cells by certain viruses is through the blocking of HS-GAG virus receptors on the susceptible cell surface. Our findings, underlining the antiviral activity of bLf, may contribute to the development of an effective approach against TosV. TosV, endemic in the Mediterranean region, could disseminate to more temperate areas in Europe with abundant vectors, emphasizing the need to consider these viruses relevant from a European public health perspective. Moreover, new agents belonging to the Phlebovirus genus, the occurrences of which are probably due to genetic exchanges between different phleboviruses, and to climatic changes increasing vector abundance and distribution, have been recently discovered [71-73]. The antiviral action of bLf against TosV, highlighted in our study, could also be of help against emerging phleboviruses potentially implicated in severe human diseases.

\section{Materials and Methods}

\subsection{Cells and Virus}

Vero cells (ATCC CCL-81; an African greenmonkey kidney cell line) were grown at $37{ }^{\circ} \mathrm{C}$ in a humidified atmosphere, with 5\% $\mathrm{CO}_{2}$ in Dulbecco's modified Eagle's medium (DMEM; Lonza, Milan, 
Italy) supplemented with 10\% inactivated fetal calf serum (FCS, Flow Laboratories, Irvine, UK.), 2 mM glutamine, 2\% non essential amino acids (Gibco, Paisley, UK), penicillin (100 IU/mL), and streptomycin $(100 \mu \mathrm{g} / \mathrm{mL})$.

TosV strain ISS.Phl.32 (isolated in 1981 from Phlebotomus perniciosus sand flies collected in Sesto Fiorentino, Florence, Italy) [74] was propagated in Vero cells and titrated by plaque assay. Briefly, after $1 \mathrm{~h}$ adsorption at $37{ }^{\circ} \mathrm{C}$ and $5 \% \mathrm{CO}_{2}$, the inoculum was aspirated and the wells were overlaid with a mixture of one part $2 \%$ Gum Tragacanth and one part $2 \times$ DMEM supplemented with $2.5 \%$ inactivated FCS and $2 \% 1 \mathrm{M}$ HEPES. The plates were incubated at $37{ }^{\circ} \mathrm{C}$ and $5 \% \mathrm{CO}_{2}$ for $4-7$ days, and then were stained with $1.5 \%$ crystal violet.

\subsection{Chemicals}

Lactoferrin from bovine milk (bLf), obtained from Morinaga Milk Industries (Zama City, Japan), was deprived of endotoxin as previously described [75]. Detoxified bLf was dissolved as a stock solution $(0.25 \mathrm{mM})$ in pyrogen-free PBS. BLf purity was checked by SDS-PAGE stained with silver nitrate and was judged to be greater than 95\%. Protein concentration was determined by UV spectroscopy on the basis of the extinction coefficient of $15.1(280 \mathrm{~nm}, 1 \%$ solution) [76]. The iron saturation rate of bLf, determined by atomic absorption spectrometry, was approximately $19.4 \%$.

Heparin (170 USP units/mg) was purchased from Sigma-Aldrich s.r.l. (Milan, Italy) and dissolved in pyrogen-free PBS to make a stock solution.

Heparinase I, II, and III from Flavobacterium heparinum were purchased from Sigma-Aldrich s.r.l. (Milan, Italy).

\subsection{Cytotoxicity Assay}

To establish the maximal non-cytotoxic dose of bLf, two-fold serial dilutions of protein in DMEM were incubated at $37{ }^{\circ} \mathrm{C}$ with confluent Vero cells grown in 96-well tissue culture microplates (Nalge Europe Ltd, Neerijse, Belgium). After 48 and 72 h, the following parameters were considered: cell morphology was examined by light microscopy, cell proliferation was evaluated quantitatively by microscopic counts after dispersion into individual cells with trypsin. Protein dilutions that did not affect any of these parameters were considered as non-cytotoxic concentrations and utilized for antiviral assays.

\subsection{Action of bLf on TosV Cytopathic Effect}

Vero cells grown in 96-well tissue culture microplates for $24 \mathrm{~h}$ at $37{ }^{\circ} \mathrm{C}$ in $5 \% \mathrm{CO}_{2}$, were incubated with different concentrations of bLf before $\left(1 \mathrm{~h}\right.$ at $\left.37^{\circ} \mathrm{C}\right)$, and during virus adsorption $\left(1 \mathrm{~h}\right.$ at $\left.37^{\circ} \mathrm{C}\right)$. As viral inoculum was utilized Tos $\mathrm{V}$ at a multiplicity of infection (m.o.i.) of 1 and 0.1 plaque forming unit (p.f.u.)/cell. Then, cells were rinsed thoroughly and incubated with the same concentrations of bLf at $37{ }^{\circ} \mathrm{C}$ in $5 \% \mathrm{CO}_{2}$. The cytopathic effect (c.p.e.) induced by TosV was measured $48 \mathrm{~h}$ after infection by the neutral red uptake assay as previously described [38]. Briefly, treated and untreated infected cells were stained for $3 \mathrm{~h}$ with neutral red $\left(50 \mu \mathrm{g} / \mathrm{mL}, 200 \mu \mathrm{L} /\right.$ well, $\left.37{ }^{\circ} \mathrm{C}, 5 \% \mathrm{CO}_{2}\right)$; then the cells were washed with Hank's salt solution and fixed for $10 \mathrm{~min}$ at room temperature (RT) with $4 \%$ formaldehyde, $10 \% \mathrm{CaCl}_{2}(200 \mu \mathrm{L} /$ well). The uptaken dye was extracted for $15 \mathrm{~min}$ at $\mathrm{RT}$ by $1 \%$ acetic acid in $50 \%$ ethanol $(200 \mu \mathrm{L} /$ well $)$ and the disruption of the cells by the virus infection or the possible protection by 
the compounds were measured at $540 \mathrm{~nm}$ by an ELISA-reader. Results were expressed as percentage of c.p.e. inhibition by comparison with untreated infected control cultures.

\subsection{Effect of bLf on Different Steps of TosV Infection}

Vero cells, grown in 96-well tissue culture microplates for $24 \mathrm{~h}$ at $37{ }^{\circ} \mathrm{C}$ in $5 \% \mathrm{CO}_{2}$, were infected with TosV ( 1 p.f.u./cell) for $1 \mathrm{~h}$ at $4{ }^{\circ} \mathrm{C}$, then viral inoculum was removed, cell monolayers were washed three times with DMEM and incubated at $37{ }^{\circ} \mathrm{C}$ in $5 \% \mathrm{CO}_{2}$. The c.p.e. induced by TosV was measured $48 \mathrm{~h}$ after infection. To ascertain whether the antiviral effect of bLf took place on viral adsorption or on a different step of viral replication, the inhibiting activity of $1 \mathrm{mg} / \mathrm{mL}$ bLf was assessed by following different experimental procedures: (i) the cells were incubated with bLf $\left(1 \mathrm{~h}\right.$ at $\left.37^{\circ} \mathrm{C}\right)$, washed three times with medium and than infected $\left(1 \mathrm{~h}\right.$ at $\left.37^{\circ} \mathrm{C}\right)$; (ii) bLf was added together with the virus inoculum during the adsorption step $\left(1 \mathrm{~h}\right.$ at $\left.37^{\circ} \mathrm{C}\right)$; (iii) bLf was incubated with the cells after the viral adsorption step $\left(48 \mathrm{~h}\right.$ at $37^{\circ} \mathrm{C}$ ); (iv) bLf was present during the whole experiment.

\subsection{Inhibition of Infection by Heparin}

Neutralization of virus binding to Vero cells was carried out by incubating serial fourfold heparin dilutions in culture medium with equal volumes $(0.25 \mathrm{~mL})$ of virus suspension containing $2.10^{5}$ p.f.u. $/ 0.25 \mathrm{~mL}$. In negative controls, culture medium was used instead of heparin in the same volume. The mixtures were incubated for $1 \mathrm{~h}$ at $37^{\circ} \mathrm{C}$. Vero cells were seeded at $2 \times 10^{4}$ in 96 -well plates (Nalge Europe Ltd, Neerijse, Belgium) $24 \mathrm{~h}$ prior to infection. Medium was removed, and the cells were infected with $100 \mu \mathrm{L} /$ well (in quadruplicate) of the virus-heparin mixtures. After $1 \mathrm{~h}$ adsorption at $37^{\circ} \mathrm{C}$, cells were rinsed thoroughly, and $200 \mu \mathrm{L}$ of fresh medium was added to the cells, followed by incubation for $48 \mathrm{~h}$ at $37^{\circ} \mathrm{C}$. Virus infection was analyzed by measuring the c.p.e. by the neutral red uptake assay.

\subsection{Enzymatic Removal of GAGs from the Surfaces of Vero Cells}

Heparinase I, II, and III were reconstituted in $20 \mathrm{mM}$ HEPES (pH 7.5), $50 \mathrm{mM} \mathrm{NaCl}, 4 \mathrm{mM} \mathrm{CaCl}$, and $0.01 \%$ bovine serum albumin (BSA). Dilutions were prepared in digestion buffer (20 mM HEPES $\mathrm{pH} 7.5,150 \mathrm{mM} \mathrm{NaCl}, 4 \mathrm{mM} \mathrm{CaCl} 2,0.1 \% \mathrm{BSA})$ and various concentrations of the enzymes (100 $\mu \mathrm{L} / \mathrm{well})$ were added to Vero cells, which were then incubated for $1 \mathrm{~h}$ at $37^{\circ} \mathrm{C}$. Cells were then washed with the respective digestion buffers and were subsequently infected with Tos $\mathrm{V}$ for $1 \mathrm{~h}$ at $37{ }^{\circ} \mathrm{C}$. After the incubation, the cells were washed twice with serum-free medium, and infectivity was determined $48 \mathrm{~h}$ post-infection by neutral red uptake assay.

\subsection{Immunofluorescence}

Vero-infected cells were washed in PBS, fixed in acetone at $-20{ }^{\circ} \mathrm{C}$ for $5 \mathrm{~min}$, and incubated with affinity purified mouse hyperimmune ascitic fluids (MIAF) anti-Toscana virus, ISS.PHL3 prototype [4], for 45 min at $37^{\circ} \mathrm{C}$. After washing in PBS, viral antigen synthesis was estimated using FITC-conjugated anti-mouse gammaglobulin antibodies (Sigma-Aldrich s.r.l., Milan, Italy) and an UV Leitz microscope. 


\subsection{Statistical Analysis}

Statistical analysis was performed by Student's $t$-test for unpaired data. Data were expressed as the mean and $\mathrm{SD}$ and $p$ values of $<0.05$ were considered significant.

\section{Conclusions}

Bovine lactoferrin strongly inhibits infection of susceptible cells by Toscana virus. The protein acts at the level of cell attachment, interfering with virus-cell binding through a competition for common glycosaminoglycan receptors. Our results provide additional insights into the antiviral efficacy of bovine lactoferrin suggesting a potential benefit of this protein against emerging phleboviruses.

\section{Acknowledgments}

This work was supported by Grants from the National Institute of Health.

\section{Author Contributions}

Conceived and designed the experiments: FS. Performed the experiments: AP, CF, MER. Analyzed the data: FS, AP, MGC. Contributed to discussion: MGC, MER, CF. Wrote the paper: FS. Contributed reagents/materials/tools: FS, MGC. All authors agree to be listed and approve the submitted version of the manuscript.

\section{Conflicts of Interest}

The authors declare no conflict of interest.

\section{References}

1. Accardi, L.; Grò, M.C.; di Bonito, P.; Giorgi, C. Toscana virus genomic L segment: Molecular cloning, coding strategy and amino acid sequence in comparison with other negative strand RNA viruses. Virus Res. 1993, 27, 119-131.

2. Grò, M.C.; di Bonito, P.; Fortini, D.; Mochi, S.; Giorgi, C. Completion of molecular characterization of Toscana phlebovirus genome: Nucleotide sequence, coding strategy of $\mathrm{M}$ genomic segment and its amino acid sequence comparison to other phleboviruses. Virus Res. 1997, 51, 81-91.

3. Verani, P.; Ciufolini, M.G.; Nicoletti, L.; Balducci, M.; Sabatinelli, G.; Coluzzi, M.; Paci, P.; Amaducci, L. Ecological and epidemiological studies of Toscana virus, an arbovirus isolated from Phlebotomus. Ann. Ist. Super. Sanità 1982, 18, 397-399.

4. Verani, P.; Nicoletti, L.; Ciufolini, M.G. Antigenic and biological characterization of Toscana virus, a new Phlebotomus fever group virus isolated in Italy. Acta Virol. 1984, 28, 39-47.

5. Charrel, R.N.; Gallian, P.; Navarro-Mari, J.M.; Nicoletti, L.; Papa, A.; Sánchez-Seco, M.P.; Tenorio, A.; de Lamballerie, X. Emergence of Toscana virus in Europe. Emerg. Infect. Dis. 2005, 11, 1657-1663.

6. Cusi, M.G.; Savellini, G.G.; Zanelli, G. Toscana virus epidemiology: From Italy to beyond. Open Virol. J. 2010, 4, 22-28. 
7. Francisci, D.; Papili, R.; Camanni, G.; Morosi, S.; Ferracchiato, N.; Valente, M.; Ciufolini, M.G.; Baldelli, F. Evidence of Toscana virus circulation in Umbria: first report. Eur. J. Epidemiol. 2003, 18, 457-459.

8. Di Nicuolo, G.; Pagliano, P.; Battisti, S.; Starace, M.; Mininni, V.; Attanasio, V.; Faella, F.S. Toscana virus central nervous system infections in southern Italy. J. Clin. Microbiol. 2005, 43, 6186-6188.

9. Venturi, G.; Madeddu, G.; Rezza, G.; Ciccozzi, M.; Pettinato, M.L.; Cilliano, M.; Fiorentini, C.; Mura, M.S.; Ciufolini, M.G. Detection of Toscana virus central nervous system infections in Sardinia Island, Italy. J. Clin. Virol. 2007, 40, 90-91.

10. Colomba, C.; Saporito, L.; Ciufolini, M.G.; Marchi, A.; Rotolo, V.; de Grazia, S.; Titone, L.; Giammanco, G.M. Prevalence of Toscana sandfly fever virus antibodies in neurological patients and control subjects in Sicily. New Microbiol. 2012, 35, 161-165.

11. Alkan, C.; Bichaud, L.; de Lamballerie, X.; Alten, B.; Gould, E.A.; Charrel, R.N. Sandfly-borne phleboviruses of Eurasia and Africa: epidemiology, genetic diversity, geographic range, control measures. Antivir. Res. 2013, 100, 54-74.

12. Nicoletti, L.; Verani, P.; Caciolli, S.; Ciufolini, M.G.; Renzi, A.; Bartolozzi, D.; Paci, P.; Leoncini, F.; Padovani, P.; Traini, E.; et al. Central nervous system involvement during infection by Phlebovirus toscana of residents in natural foci in central Italy (1977-1988). Am. J. Trop. Med. Hyg. 1991, 45, 429-434.

13. Dupouey, J.; Bichaud, L.; Ninove, L.; Zandotti, C.; Thirion-Perrier, L.; de Lamballerie, X.; Charrel, R.N. Toscana virus infections: A case series from France. J. Infect. 2014, 68, 290-295.

14. Tesh, R.B. The genus Phlebovirus and its vectors. Annu. Rev. Entomol. 1988, 33, 169-181.

15. Braito, A.; Corbisiero, R.; Corradini, S.; Marchi, B.; Sancasciani, N.; Fiorentini, C.; Ciufolini, M.G. Evidence of Toscana virus infections without central nervous system involvement: A serological study. Eur. J. Epidemiol. 1997, 13, 761-764.

16. Braito, A.; Ciufolini, M.G.; Pippi, L.; Corbisiero, R.; Fiorentini, C.; Gistri, A.; Toscano, L. Phlebotomus-transmitted Toscana virus infections of the central nervous system: A seven-year experience in Tuscany. Scand. J. Infect. Dis. 1998, 30, 505-508.

17. Braito, A.; Corbisiero, R.; Corradini, S.; Fiorentini, C.; Ciufolini, M.G. Toscana virus infections of the central nervous system in children: A report of 14 cases. J. Pediatr. 1998, 132, 144-148.

18. Valassina, M.; Meacci, F.; Valensin, P.E.; Cusi, M.G. Detection of neurotropic viruses circulating in Tuscany: The incisive role of Toscana virus. J. Med. Virol. 2000, 60, 86-90.

19. Valassina, M.; Cusi, M.G.; Valensin, P.E. A Mediterranean arbovirus: the Toscana virus. J. Neurovirol. 2003, 9, 577-583.

20. Valassina, M.; Valentini, M.; Pugliese, A.; Valensin, P.E.; Cusi, M.G. Serological survey of Toscana virus infections in a high-risk population in Italy. Clin. Diagn. Lab. Immunol. 2003, 10, 483-484.

21. Dionisio, D.; Valassina, M.; Ciufolini, M.G.; Vivarelli, A.; Esperti, F.; Cusi, M.G.; Marchi, A.; Mazzoli, F.; Lupi, C. Encephalitis without meningitis due to sandfly fever virus serotype toscana. Clin. Infect. Dis. 2001, 32, 1241-1243. 
22. Baldelli, F.; Ciufolini, M.G.; Francisci, D.; Marchi, A.; Venturi, G.; Fiorentini, C.; Luchetta, M.L.; Bruto, L.; Pauluzzi, S. Unusual presentation of life-threatening Toscana virus meningoencephalitis. Clin. Infect. Dis. 2004, 38, 515-520.

23. Zanelli, G.; Bianco, C.; Cusi, M.G. Testicular involvement during Toscana virus infection: An unusual manifestation? Infection 2013, 41, 735-736.

24. Martinez-Garcia, F.A.; Moreno-Docon, A.; Lopez-Lopez, M.; Albert-Lacal, L.; Martinez-Toldos, M.C.; Segovia-Hernandez, M.; Fernandez-Barreiro, A. A case of meningitis due to Toscana virus in Murcia. Rev. Neurol. 2007, 45, 317-318.

25. Pauli, C.; Schwarz, T.F.; Meyer, C.G.; Jager, G. Neurological symptoms after an infection by the sandfly fever virus. Dtsch. Med. Wochenschr. 1995, 120, 1468-1472.

26. Serata, D.; Rapinesi, C.; del Casale, A.; Simonetti, A.; Mazzarini, L.; Ambrosi, E.; Kotzalidis, G.D.; Fensore, C.; Girardi, P.; Tatarelli, R. Personality changes after Toscana virus (Toscana virus) encephalitis in a 49-year-old man: A case report. Int. J. Neurosci. 2011, 121, 165-169.

27. Kuhn, J.; Bewermeyer, H.; Hartmann-Klosterkoetter, U.; Emmerich, P.; Schilling, S.; Valassina, M. Toscana virus causing severe meningoencephalitis in an elderly traveller. J. Neurol. Neurosurg. Psychiatry 2005, 76, 1605-1606.

28. Bartels, S.; de Boni, L.; Kretzschmar, H.A.; Heckmann, J.G. Lethal encephalitis caused by the Toscana virus in an elderly patient. J. Neurol. 2012, 259, 175-177.

29. Legrand, D.; Mazurier, J.; Colavizza, D.; Montreuil, J.; Spik, G. Properties of the iron-binding site of the N-terminal lobe of human and bovine lactotransferrins. Importance of the glycan moiety and of the non-covalent interactions between the $\mathrm{N}$ - and C-terminal lobes in the stability of the iron-binding site. Biochem. J. 1990, 266, 575-581.

30. Gennaro, R.; Dewald, B.; Horisberger, U.; Gubler, H.U.; Baggiolini, M. A novel type of cytoplasmic granule in bovine neutrophils. J. Cell Biol. 1983, 96, 1651-1661.

31. Levay, P.F.; Viljoen, M. Lactoferrin: A general review. Haematologica 1995, 80, 252-267.

32. Vorland, L.H. Lactoferrin: A multifunctional glycoprotein. APMIS 1999, 107, 971-981.

33. Van der Strate, B.W.A.; Beljaars, L.; Molema, G.; Harmsen, M.C.; Meijer, D.K.F. Antiviral activities of lactoferrin. Antivir. Res. 2001, 52, 225-239.

34. Marchetti, M.; Superti, F. Recent developments in antiviral research. In Antiviral Activity of Lactoferrin; Pandalai, S.G., Eds.; Transworld Research Network: Trivandrum, India, 2001; pp. 193-203.

35. Harmsen, M.C.; Swart, P.J.; de B'ethune, M.P.; Pawels, R.; de Clercq, E.; Th'e, T.H.; Meijer, D.K.F. Antiviral effects of plasma and milk proteins: lactoferrin shows a potent activity against both human immunodeficiencyvirus and human cytomegalovirus replication in vitro. J. Infect. Dis. 1995, 172, 380-388.

36. Beljaars, L.; van der Strate, B.W.; Bakker, H.I.; Reker-Smit, C.; van Loenen-Weemaes, A.M.; Wiegmans, F.C.; Harmsen, M.C.; Molema, G.; Meijer, D.K. Inhibition of cytomegalovirus infection by lactoferrin in vitro and in vivo. Antivir. Res. 2004, 63, 197-208.

37. Hasegawa, K.; Motsuchi, W.; Tanaka, S.; Dosako, S. Inhibition with lactoferrin of in vitro infection with human herpes virus. Jpn. J. Med. Sci. Biol. 1994, 47, 73-85. 
38. Marchetti, M.; Trybala, E.; Superti, F.; Johansson, M.; Bergström, T. Inhibition of herpes simplex virus infection by lactoferrin is dependent on interference with the virus binding to glycosaminoglycans. Virology 2004, 18, 405-413.

39. Marchetti, M.; Ammendolia, M.G.; Superti, F. Glycosaminoglycans are not indispensable for the anti-herpes simplex virus type 2 activity of lactoferrin. Biochimie 2009, 91, 155-159.

40. Ammendolia, M.G.; Marchetti, M.; Superti, F. Bovine lactoferrin prevents the entry and intercellular spread of herpes simplex virus type 1 in Green Monkey Kidney cells. Antivir. Res. 2007, 76, 252-262.

41. Yi, M.; Kaneko, S.; Yu, D.Y.; Murakami, S. Hepatitis C virus envelope proteins bind lactoferrin. J. Virol. 1997, 71, 5997-6002.

42. Murphy, M.E.; Kariwa, H.; Mizutani, T.; Yoshimatsu, K.; Arikawa, J.; Takashima, I. In vitro antiviral activity of lactoferrin and ribavirin upon hantavirus. Arch. Virol. 2000, 145, 1571-1582.

43. Hara, K.; Ikeda, M.; Saito, S.; Matsumoto, S.; Numata, K.; Kato, N.; Tanaka, K.; Sekihara, H. Lactoferrin inhibits hepatitis B virus infection in cultured human hepatocytes. Hepatol. Res. 2002, 24, 228-235.

44. Sano, H.; Nagai, K.; Tsutsumi, H.; Kuroki, Y. Lactoferrin and surfactant protein A exhibit distinct binding specificity to $\mathrm{F}$ protein and differently modulate respiratory syncytial virus infection. Eur. J. Immunol. 2003, 33, 2894-2902.

45. Pietrantoni, A.; Dofrelli, E.; Tinari, A.; Ammendolia, M.G.; Puzelli, S.; Fabiani, C.; Donatelli, I.; Superti, F. Bovine lactoferrin inhibits influenza A virus induced programmed cell death in vitro. Biometals 2010, 23, 465-475.

46. Pietrantoni, A.; Ammendolia, M.G.; Superti, F. Bovine lactoferrin: involvement of metal saturation and carbohydrates in the inhibition of influenza virus infection. Biochem. Cell Biol. 2012, 90, 442-448.

47. Chien, Y.J.; Chen, W.J.; Hsu, W.L.; Chiou, S.S. Bovine lactoferrin inhibits Japanese encephalitis virus by binding to heparan sulfate and receptor for low density lipoprotein. Virology 2008, 379, 143-151.

48. Carvalho, C.A.; Sousa, I.P., Jr.; Silva, J.L.; Oliveira, A.C.; Gonçalves, R.B.; Gomes, A.M. Inhibition of Mayaro virus infection by bovine lactoferrin. Virology 2014, 452-453, 297-302.

49. Zou, S.; Magura, C.E.; Hurley, W.L. Heparin-binding properties of lactoferrin and lysozyme. Comp. Biochem. Physiol. 1992, 103, 889-895.

50. De Boer, S.M.; Kortekaas, J.; de Haan, C.A.; Rottier, P.J.; Moormann, R.J.; Bosch, B.J. Heparan sulfate facilitates Rift Valley fever virus entry into the cell. J. Virol. 2012, 86, 13767-13771.

51. Chen, Y.; Maguire, T.; Hileman, R.E.; Fromm, J.R.; Esko, J.D.; Linhardt, R.J.; Marks, R.M. Dengue virus infectivity depends on envelope protein binding to target cell heparan sulfate. Nat. Med. 1997, 3, 866-871.

52. Wakabayashi, H.; Oda, H.; Yamauchi, K.; Abe, F. Lactoferrin for prevention of common viral infections. J. Infect. Chemother. 2014, doi:10.1016/j.jiac.2014.08.003.

53. Waarts, B.L.; Aneke, O.J.; Smit, J.M.; Kimata, K.; Bittman, R.; Meijer, D.K.; Wilschut, J. Antiviral activity of human lactoferrin: Inhibition of alphavirus interaction with heparan sulfate. Virology 2005, 333, 284-292. 
54. Shimazaki, K.; Tazume, T.; Uji, K.; Tanaka, M.; Kumura, H.; Mikawa, K.; Shimo-Oka, T. Properties of a Heparin-binding peptide derived from bovine lactoferrin. J. Dairy Sci. 1998, 81, 2841-2849.

55. Shimazaki, K.; Uji, K.; Tazume, T.; Kumura, H.; Shimo-Oka, T. Approach to identification and comparison of the heparin-interacting sites of lactoferrin using synthetic peptides. In Lactoferrin: Structure, Function and Applications; Shimazaki, K., Tsuda, H., Tomita, M., Kuwata, T., Perraudin, J.P., Eds.; Elsevier Science B.V: Amsterdam, The Netherland, 2000; pp. 37-46.

56. Haywood, A.M. Virus receptors: Binding, adhesion, strengthening, and changes in viral structure. J. Virol. 1994, 68, 1-5.

57. Rostand, K.S.; Esko, J.D. Microbial adherence to and invasion through proteoglycans. Infect. Immun. 1997, 6, 1-8.

58. Byrnes, A.P.; Griffin, D.E. Binding of Sindbis virus to cell surface heparan sulfate. J. Virol. 1998, 72, 7349-7356.

59. Bernard, K.A.; Klimstra, W.B.; Johnston, R.E. Mutations in the E2 glycoprotein of Venezuelan equine encephalitis virus confer heparan sulfate interaction, low morbidity, and rapid clearance from blood of mice. Virology 2000, 276, 93-103.

60. Summerford, C.; Samulski, R.J. Membrane-associated heparan sulfate proteoglycan is a receptor for adeno-associated virus type 2 virions. J. Virol. 1998, 72, 1438-1445.

61. Jackson, T.; Ellard, F.M.; Ghazaleh, R.A.; Brookes, S.M.; Blakemore, W.E.; Corteyn, A.H.; Stuart, D.I.; Newman, J.W.; King, A.M. Efficient infection of cells in culture by type O foot-and-mouth disease virus requires binding to cell surface heparan sulfate. J. Virol. 1996, 70, 5282-5287.

62. Compton, T.; Nowlin, D.M.; Cooper, N.R. Initiation of human cytomegalovirus-infection requires initial interaction with cell surface heparan sulfate. Virology 1993, 193, 834-841.

63. Birkmann, A.; Mahr, K.; Ensser, A.; Yaguboglu, S.; Titgemeyer, F.; Fleckenstein, B.; Neipel, F. Cell surface heparan sulfate is a receptor for human herpesvirus 8 and interacts with envelope glycoprotein K8.1. J. Virol. 2001, 75, 11583-11593.

64. Shukla, D.; Spear, P.G. Herpesviruses and heparan sulfate: An intimate relationship in aid of viral entry. J. Clin. Invest. 2001, 108, 503-510.

65. Trybala, E.; Roth, A.; Johansson, M.; Liljeqvist, J.A.; Rekabdar, E.; Larm, O.; Bergstrom, T. Glycosaminoglycan-binding ability is a feature of wild-type strains of herpes simplex virus type 1. Virology 2002, 302, 413-419.

66. Patel, M.; Yanagishita, M.; Roderiquez, G.; Bouhabib, D.C.; Oravecz, T.; Hascall, V.C.; Norcross, M.A. Cell surface heparan sulfate proteoglycan mediates HIV-1 infection of T-cell lines. Aids Res. Hum. Retrovir. 1993, 9, 167-174.

67. Goodfellow, I.G.; Sioofy, A.B.; Powell, R.M.; Evans, D.J. Echoviruses bind heparan sulfate at the cell surface. J. Virol. 2001, 75, 4918-4921.

68. Germi, R.; Crance, J.M.; Garin, D.; Guimet, J.; Lortat-Jacob, H.; Ruigrok, R.W.; Zarski, J.P.; Drouet, E. Heparan sulfate-mediated binding of infectious dengue virus type 2 and yellow fever virus. Virology 2002, 292, 162-168.

69. Dechecchi, M.C.; Melotti, P.; Bonizzato, A.; Santacatterina, M.; Chilosi, M.; Cabrini, G. Heparan sulfate glycosaminoglycans are receptors sufficient to mediate the initial binding of adenovirus types 2 and 5. J. Virol. 2001, 75, 8772-8780. 
70. Liu, J.; Thorp, S.C. Cell surface heparan sulfate and its roles in assisting viral infections. Med. Res. Rev. 2002, 22, 1-25.

71. Depaquit, J.; Grandadam, M.; Fouque, F.; Andry, P.E.; Peyrefitte, C. Arthropod-borne viruses transmitted by Phlebotomine sandflies in Europe: A review. Euro Surveill. 2010, 15, e19507.

72. Peyrefitte, C.N.; Grandadam, M.; Bessaud, M.; Andry, P.E.; Fouque, F.; Caro, V.; Diancourt, L.; Schuffenecker, I.; Pagès, F.; Tolou, H.; et al. Diversity of Phlebotomus perniciosus in Provence, southeastern France: Detection of two putative new phlebovirus sequences. Vector Borne Zoonotic Dis. 2013, 13, 630-636.

73. Remoli, M.E.; Fortuna, C.; Marchi, A.; Bucci, P.; Argentini, C.; Bongiorno, G.; Maroli, M.; Gradoni, L.; Gramiccia, M.; Ciufolini, M.G. Viral isolates of a novel putative phlebovirus in the Marche Region of Italy. Am. J. Trop. Med. Hyg. 2014, 90, 760-763.

74. Venturi, G.; Ciccozzi, M.; Montieri, S.; Bartoloni, A.; Francisci, D.; Nicoletti, L.; Fortuna, C.; Marongiu, L.; Rezza, G.; Ciufolini, M.G. Genetic variability of the M genome segment of clinical and environmental Toscana virus strains. J. Gen. Virol. 2007, 88, 1288-1294.

75. Pietrantoni, A.; Ammendolia, M.G.; Tinari, A.; Siciliano, R.; Valenti, P.; Superti, F. Bovine lactoferrin peptidic fragments involved in inhibition of Echovirus 6 in vitro infection. Antivir. Res. 2006, 69, 98-106.

76. Groves, M.L. The isolation of a red protein from milk. J. Am. Chem. Soc. 1960, 82, 3345-3350.

(C) 2015 by the authors; licensee MDPI, Basel, Switzerland. This article is an open access article distributed under the terms and conditions of the Creative Commons Attribution license (http://creativecommons.org/licenses/by/4.0/). 